\title{
Immunological Significance of Cytotoxic T Lymphocyte Epitope Variants in Patients Chronically Infected by the Hepatitis C Virus
}

\author{
Kyong-Mi Chang, ${ }^{\star}$ Barbara Rehermann,,${ }^{\ddagger}$ John G. McHutchison, ${ }^{\S}$ Claudio Pasquinelli, ${ }^{\star}$ Scott Southwood, Alessandro Sette, \\ and Francis V. Chisari* \\ *Department of Molecular \& Experimental Medicine, The Scripps Research Institute, La Jolla, CA 92037; ${ }^{\ddagger}$ Abteilung Gastroenterologie \\ und Hepatologie, Medizinische Hochschule Hannover, 30625 Hannover, Germany; ${ }^{\S}$ Department of Gastroenterology, The Scripps \\ Research Institute, La Jolla, California 92037; and ${ }^{\|}$Department of Immunology, Cytel Corporation, San Diego, CA 92121
}

\begin{abstract}
This study was performed to test the hypothesis that cytotoxic T lymphocyte (CTL) selection of hepatitis $\mathrm{C}$ virus (HCV) escape variants plays a role in $\mathrm{HCV}$ persistence. The peripheral blood CTL responsiveness of patients with wellestablished chronic hepatitis $\mathrm{C}$ to a panel of 10 prototype HCV peptides (genotype 1a) was compared with the corresponding sequences encoded by the infecting viruses in each patient. Variant viral peptide sequences were threefold more frequent in the presence of a CTL response than in its absence, and CTL responses were detected nearly twice as often in association with variant rather than with prototype viral peptide sequences. Furthermore, over half of the patients were infected with potential CTL escape variants that contained nonimmunogenic and noncross-reactive variant peptides many of which displayed reduced HLA-binding affinity. Surprisingly, follow up analysis over a period of up to 46 mo revealed that, in contrast to the relatively high frequency of escape variants initially observed, the subsequent emergence rate of CTL escape variants was very low. Interestingly, the one escape variant that was detected proved to be a CTL antagonist. Collectively, these observations suggest that CTL selection of epitope variants may have occurred in these patients before their entrance into the study and that it may have played a role in $\mathrm{HCV}$ persistence. The low apparent rate of ongoing CTL selection in chronically infected patients, however, suggests that if CTL escape occurs during $\mathrm{HCV}$ infection it is probably an early event. ( $J$. Clin. Invest. 1997. 100:2376-2385.) Key words: hepatitis C virus $\bullet$ cytotoxic T lymphocytes $\cdot$ CTL escape $\bullet$ viral persistence $\cdot$ HLA-binding
\end{abstract}

\section{Introduction}

Hepatitis $\mathrm{C}$ virus $(\mathrm{HCV})^{1}$ is an hepatotropic RNA virus that causes persistent infection in the majority of exposed individu-

Address correspondence to Francis V. Chisari, M.D., Department of Molecular and Experimental Medicine, The Scripps Research Institute, 10550 North Torrey Pines Road, La Jolla, CA 92037. Phone: 619-784-8228; FAX: 619-784-2160; E-mail: fchisari@scripps.edu

Received for publication 17 June 1997 and accepted in revised form 11 September 1997.

J. Clin. Invest.

(C) The American Society for Clinical Investigation, Inc. 0021-9738/97/11/2376/10 \$2.00

Volume 100, Number 9, November 1997, 2376-2385

http://www.jci.org als in the face of a humoral and cellular immune response to its antigens (1-13). The role of virus-specific cytotoxic T lymphocytes (CTL) in HCV pathogenesis is not yet clear. We have reported that the frequency of peripheral blood CTL precursors specific for individual HCV epitopes is relatively low, and that it does not correlate with viral load or disease activity in chronic HCV patients (8). However, when the sum of the CTL responses against a panel of 10 independent HCV CTL epitopes is quantitated, the combined strength of the CTL response to all of the epitopes is significantly higher in patients with low viral load than in patients with high viral load (9). A similar inverse correlation between the viral load and CTL response to a human leukocyte antigen (HLA)-B44 restricted epitope has also been described by Hiroishi et al. (14).

Because of the fluctuating quasispecies nature of $\mathrm{HCV}$ as a result of the high intrinsic error rate of the viral polymerase (15-18), it has been hypothesized that immune selection of CTL escape variants may be responsible for $\mathrm{HCV}$ persistence (19-22). In keeping with this notion, the emergence of a CTL escape variant has been reported in an experimentally infected chimpanzee who subsequently developed chronic HCV infection (22). However, the overall importance of CTL escape variants in HCV persistence is controversial $(19,23)$. Since the $\mathrm{HCV}$-specific CTL response is multispecific, the loss of a single epitope is unlikely to confer a significant survival advantage to the variant virus unless that particular response is strongly immunodominant or the apparently multispecific CTL response actually reflects the accumulation of a series of monospecific CTL responses from which the virus has sequentially escaped. Nonetheless, the inverse relationship observed between CTL responsiveness and viral load $(9,14)$ is consistent with the notion that CTL could also exert selection pressure in vivo. In any event, simultaneous analysis of the viral nucleotide sequence and the CTL response to multiple CTL epitopes in the same individual is necessary to determine the potential contribution of CTL escape variants to HCV persistence.

In this study, we tested the hypothesis that CTL pressure results in selection of escape variants and that this plays a role in persistent $\mathrm{HCV}$ infection. To this end, we analyzed the CTL response to the panel of $10 \mathrm{HCV}-1$ (genotype 1a)-derived prototype peptides, previously identified as CTL epitopes $(4,8,9)$, in 13 HLA-A2 positive patients with chronic HCV infection. We then determined the corresponding viral peptide se-

1. Abbreviations used in this paper: ALT, alanine aminotransferase; CRI-P, CTL response index for each peptide; CTL, cytotoxic T lymphocytes; EA, external antisense; ES, external sense; HBV, hepatitis $B$ virus; $\mathrm{HCV}$, hepatitis $\mathrm{C}$ virus; HLA, human leukocyte antigen; IA, internal antisense; IS, internal sense. 
quences from $\mathrm{HCV}$ isolates derived from the sera of these patients. Next, we examined the immunological significance of the naturally occurring variant viral peptide sequences in these patients by monitoring their immunogenicity and cross-reactivity with the prototype specific CTL. Finally, to estimate the role of ongoing CTL selection pressure in the generation of viral variants during chronic infection, viral sequence analysis was performed on blood obtained at a later time point in selected cases.

\section{Methods}

Patients. 13 HLA-A2 positive patients with chronic HCV infection were studied. Chronic HCV infection was defined by the presence of the following criteria: HCV antibody detected by the second generation Ortho HCV enzyme-linked immunosorbent assay test system (Ortho Diagnostic Systems, Inc., Raritan, NJ), presence of HCV RNA by reverse transcriptase-polymerase chain reaction (RT-PCR) as described below, elevated serum alanine aminotransferase (ALT) activity for over $6 \mathrm{mo}$ and liver histology consistent with chronic hepatitis C. Other inclusion criteria included the availability of HCV RNA positive serum samples obtained from at least two separate time points (T1 and T2, at least 9 mo apart), and PBMC for CTL analysis. None of the patients had other known causes of chronic liver disease (e.g., chronic HBV, autoimmune hepatitis, hemochromatosis) or HIV coinfection. At T1, none of the patients had been treated with interferon whereas all patients had received interferon treatment between T1 and T2. 15 healthy HLA-A2 positive blood donors (normal ALT, no history of liver disease, and negative for HCV antibody, HIV antibody, hepatitis B surface antigen [HBsAg], and hepatitis B core antibody $[\mathrm{HBcAb}]$ in the serum) were studied as normal controls. HLA typing of PBMC by complement-dependent microcytotoxicity was performed with Terasaki HLA-typing trays (One Lambda Inc., Canoga Park, CA) according to the manufacturer's instructions, as described previously $(4,8,9)$. The clinical and virological characteristics of the patients are shown on Table I.
Sera and $P B M C$. Serum samples were stored at $-80^{\circ} \mathrm{C}$ immediately after collection. PBMC from each patient were separated on Ficoll-Histopaque density gradient (Sigma Chemical Co., St. Louis, MO), washed three times in HBSS (GIBCO BRL, Gaithersburg, $\mathrm{NY}$ ), and either used immediately or cryopreserved in media containing $80 \%$ FCS (GIBCO BRL), $10 \%$ dimethyl sulfoxide (Sigma Chemical Co.), and 10\% RPMI1640 (GIBCO BRL). To study the effect of CTL pressure on HCV epitope sequence, viral sequence analysis was performed on serum samples from two different bleed dates. The first serum sample was obtained at the beginning of the study period (T1) at the time of or before the CTL analysis, and the second sample was obtained at a second time point (T2) after the CTL analysis. The average length of time between the collection of two serum samples was $\sim 22$ mo (range 9-46 mo).

Synthetic peptides. Prototype HCV-1-derived peptides previously reported as HLA-A2-restricted HCV epitopes (shown in Table II) and variant (non-HCV-1) peptides corresponding to the infecting viral epitope sequences from individual patients were synthesized with a free amine $\mathrm{NH}_{2}$ terminus and a free acid $\mathrm{COOH}$ terminus by Chiron Mimotopes Pty Ltd. (Clayton, Australia) or by the Scripps Research Institute Core Facility (La Jolla, CA). The prototype peptide sequences were based on HCV-1 (genotype 1a) since most viral isolates in the USA belong to genotype 1a (20). Lyophilized peptides were reconstituted at $20 \mathrm{mg} / \mathrm{ml}$ in dimethyl sulfoxide (Mallinckrodt, Paris, KY) and diluted to $1 \mathrm{mg} / \mathrm{ml}$ with RPMI 1640 medium (GIBCO BRL) as described previously $(4,8,9)$. Throughout the text, the term "prototype" is used to indicate viral peptide sequences identical to the HCV-1-derived peptide sequence. Similarly, the term "variant" is used to indicate peptide sequences derived from the patients' viral isolates that are different from the corresponding prototype $\mathrm{HCV}-1$ peptides. The peptides that have been shown to be immunogenic (e.g. the panel of $10 \mathrm{HCV}-1$ peptides) are also interchangeably referred to as "epitopes."

Stimulation of PBMC with synthetic peptides. Cryopreserved PBMC (rapidly thawed at $37^{\circ} \mathrm{C}$ and washed three times in cold HBSS) or freshly isolated PBMC were resuspended in RPMI 1640 supplemented with L-glutamine ( $2 \mathrm{mM})$, gentamycin $(10 \mathrm{mM})$ (GIBCO BRL) and $10 \%$ heat-inactivated human $\mathrm{AB}$ serum at $4 \times 10^{6}$ cells per milli-

Table I. Patient Characteristics*

\begin{tabular}{|c|c|c|c|c|c|c|c|c|c|c|}
\hline \multirow[b]{3}{*}{$\begin{array}{l}\text { Patient } \\
\text { I.D. }\end{array}$} & \multirow[b]{3}{*}{$\begin{array}{l}\text { Age } \\
(\mathrm{yr})\end{array}$} & \multirow[b]{3}{*}{ Sex } & \multirow[b]{3}{*}{ Genotype } & \multicolumn{3}{|c|}{$\mathrm{T} 1 * *$} & \multicolumn{3}{|c|}{$\mathrm{T} 2 * *$} & \multirow[b]{3}{*}{$\begin{array}{l}\text { Study period } \\
(\mathrm{mo})^{* * * *}\end{array}$} \\
\hline & & & & \multirow{2}{*}{$\begin{array}{c}\text { ALT } \\
\text { (U/liter) }\end{array}$} & \multicolumn{2}{|c|}{ HCV RNA } & \multirow{2}{*}{$\begin{array}{c}\text { ALT } \\
\text { (U/liter) }\end{array}$} & \multicolumn{2}{|c|}{ HCV RNA } & \\
\hline & & & & & bDNA no. & PCR & & bDNA no. & PCR & \\
\hline 1 & 52 & $\mathrm{M}$ & $1 \mathrm{a}$ & 217 & 113 & + & 171 & $<3.5$ & + & 11 \\
\hline 2 & 35 & M & $2 b$ & 208 & 55 & + & ND & $<3.5$ & + & 19 \\
\hline 3 & 42 & $\mathrm{M}$ & $1 \mathrm{a}$ & 296 & 110 & + & 229 & 4.6 & + & 28 \\
\hline 4 & 38 & $\mathrm{~F}$ & $1 \mathrm{~b}$ & 98 & 61 & + & 74 & 67 & + & 9 \\
\hline 5 & 38 & $\mathrm{M}$ & $1 \mathrm{a}$ & 155 & $<3.5$ & + & 29 & 70 & + & 21 \\
\hline 6 & 62 & $\mathrm{~F}$ & $1 \mathrm{a}$ & 190 & 50 & + & 173 & 30 & + & 21 \\
\hline 7 & 37 & $\mathrm{M}$ & $1 \mathrm{~b}$ & 140 & 20 & + & 93 & $<3.5$ & + & 38 \\
\hline 8 & 32 & $\mathrm{M}$ & $1 \mathrm{a}$ & 238 & ND & + & 221 & $<3.5$ & + & 46 \\
\hline 9 & 43 & $\mathrm{~F}$ & $1 \mathrm{a}$ & 77 & 51 & + & 27 & $<3.5$ & + & 14 \\
\hline 10 & 34 & $\mathrm{~F}$ & $2 b$ & 74 & $<3.5$ & + & 117 & $<3.5$ & + & 10 \\
\hline 11 & 29 & $\mathrm{M}$ & $1 \mathrm{~b}$ & 81 & 120 & + & 102 & 42 & + & 14 \\
\hline 12 & 40 & $\mathrm{M}$ & $1 \mathrm{a}$ & 75 & 33 & + & 64 & 82 & + & 9 \\
\hline 13 & 41 & $\mathrm{M}$ & $3 a$ & 230 & 5 & + & ND & $<3.5$ & + & 45 \\
\hline Mean & 40 & & & 160 & & & 118 & & & 22 \\
\hline
\end{tabular}

* All patients were anti-HCV positive by second generation Ortho HCV enzyme-linked immunosorbent assay test (Ortho Diagnostics, Inc., Raritan, $\mathrm{NJ})$. ${ }^{* *} T 1$, time of first sequence analysis; $T 2$, time of second sequence analysis. ***Time between $\mathrm{T} 1$ and $\mathrm{T} 2$. No. bDNA: $\times 10^{5}$ viral genome equivalents per milliliter. $N D$, not done. 
liter. To screen the entire panel of 10 prototype peptides, $0.1 \mathrm{ml}$ of cell suspension $\left(4 \times 10^{5}\right.$ cells per well $)$ were plated in eight replicate wells for each peptide in round-bottomed 96-well plates as described previously $(8,9)$. To study CTL specific for the naturally occurring variant peptides, PBMC were stimulated separately with the variant peptide and with the corresponding prototype peptide in 24-well plates $\left(10 \mu \mathrm{g}\right.$ peptide per milliliter, $4 \times 10^{6} \mathrm{PBMC} / \mathrm{ml}, 1 \mathrm{ml}$ final volume) to obtain sufficient number of effectors to test for immunogenicity and cross-reactivity of each peptide at varying E/T ratios. The cultures were restimulated on days 7 and 14 with autologous irradiated $(3,000 \mathrm{rad})$ PBMC $\left(1 \times 10^{6}\right.$ cells per milliliter $)$ and peptide $(10 \mu \mathrm{g} / \mathrm{ml})$, and on days 3,10 , and 18 with $20 \mathrm{U} / \mathrm{ml}$ of recombinant human interleukin-2 (rIL-2) (Hoffmann-La Roche, Inc., Nutley, NJ) in fresh media as described previously $(8,9)$.

Cytotoxicity assay. Cultures were tested for peptide-specific cytolytic activity on day 21 in a standard $4 \mathrm{~h}{ }^{51} \mathrm{Cr}$ release assay using round-bottomed 96-well plates containing 3,000 target cells per well. An allogeneic HLA-A2 positive Epstein-Barr virus (EBV)-transformed B cell line (JY, HLA-A2.1, B7, Cw7) pulsed overnight with peptide $(10 \mu \mathrm{g} / \mathrm{ml})$ and labeled for $1 \mathrm{~h}$ with ${ }^{51} \mathrm{Cr}(0.1 \mathrm{mCi})$ was used as target cells in these assays as described previously $(4,8,9)$. Percent cytotoxicity was calculated using the following formula: $100 \times[($ experimental release-spontaneous release)/(maximum release-spontaneous release)]. Maximum release was determined with $10 \%$ Triton X-100 (Mallinckrodt). Spontaneous release was always less than $25 \%$.

The CTL response index for each peptide (CRI-P), representing the sum of the peptide-specific cytotoxicity detected in eight replicate wells for each prototype peptide, was calculated as described previously $(8,9)$. CRI-P unit values $\geq 3$ SD above the mean CRI-P obtained from the uninfected controls for each peptide were considered positive (8). The cutoff unit values for the 10 peptides are as follows: peptide 1 (52.3 U); peptide 2 (79.8 U); peptide 3 (28.9 U); peptide 4 (39.4 U); peptide 5 (43.0 U); peptide 6 (25.1 U); peptide 7 (49.0 U); peptide 8 (50.7 U); peptide 9 (93.2 U); peptide 10 (41.0 U) (8). CTL cross-reactivity was determined by testing the ability of effectors stimulated with prototype peptide to lyse targets pulsed with the variant peptide in a standard $4 \mathrm{~h}{ }^{51} \mathrm{Cr}$ release assay at varying E/T ratios. Variant immunogenicity was determined by testing effectors stimulated by the variant peptide to lyse targets pulsed with the variant peptide at varying $\mathrm{E} / \mathrm{T}$ ratios. After 3 wk of culture, a peptide-specific cytotoxicity $>12 \%$ at an $\mathrm{E} / \mathrm{T}$ ratio of $60: 1$ was arbitrarily defined as positive for the 24-well cultures.

Antagonist assay. The ability of a variant peptide to antagonize the lytic activity of prototype peptide specific CTL was determined using the method described by Bertoletti et al. (24). Briefly, target cells were pulsed overnight with the prototype peptide at varying concentrations $(0.1,0.3$, and $1.0 \mu \mathrm{M})$, labeled with ${ }^{51} \mathrm{Cr}(0.1 \mathrm{mCi})$ for $1 \mathrm{~h}$, washed four times with HBSS, and further pulsed with varying concentrations of the variant peptide $(0.1,1.0$, and $10 \mu \mathrm{M})$ for $1 \mathrm{~h}$ before a $4-\mathrm{h}{ }^{51} \mathrm{Cr}$ release assay with the prototype peptide specific CTL. Controls included targets pulsed with only the prototype peptide, only the variant, or with no peptide. Percent inhibition of cytotoxicity was determined using the following formula: $100 \times[(\%$ specific cytotoxicity for prototype target $)-(\%$ specific cytotoxicity for prototype + variant target $)] /(\%$ specific cytotoxicity for prototype target $)$.

HLA-Binding Analysis. HLA-A2.1 binding affinities of select variant and prototype peptides were measured by their ability to competitively inhibit binding of radiolabeled control peptide to HLAA2.1 molecules in vitro as described previously (25).

Detection of HCV RNA. Total RNA was extracted from sera of patients using the GTC-phenol method described by Chomczynski and Sacchi (26). Reverse transcription was performed using Superscript II reverse transcriptase (GIBCO BRL) and random hexamer (GIBCO BRL) following the manufacturer's instructions as we have described previously $(8,9)$. HCV sequences were amplified with Taq Polymerase (Boehringer Mannheim Biochemicals, Indianapolis, IN) using a nested primer set derived from the highly conserved $5^{\prime}$ untranslated region as described previously $(8,9)$. The PCR products were analyzed on a $1.5 \%$ agarose gel and visualized by ethidium bromide staining.

$H C V$ genotype and viral load determination. The genotype of the infecting virus was determined by aligning the viral sequence with the published GenBank sequences and also by Inno-Lipa Assay (courtesy of Dr. Andrew Conrad, National Genetics Institute, Los Angeles, CA). Viral load was quantified in serum using the bDNA nucleic hybridization assay Quantiplex ${ }^{\mathrm{TM}}$ (Chiron Corp., Emeryville, CA) according to the manufacturer's instructions (courtesy of Dr. Robert Kokka, Chiron Corp).

Sequence analysis. The overall strategy was to determine the viral peptide sequence corresponding to the 10 epitopes RT-PCR and direct sequencing using sera obtained at the earliest time point (T1), and also at a second time point (T2) if the first sequence was identical to the prototype sequence. For comparison, 22 viral peptides that were variant at $\mathrm{T} 1$ were also sequenced at $\mathrm{T} 2$. Viral RNA was extracted and reverse transcribed as described above. The viral cDNA was amplified by PCR with appropriate precautions to prevent PCR contamination as described by Kwok and Higuchi (27), and the PCR products were analyzed on a $1.5 \%$ agarose gel and visualized by ethidium bromide staining. The primer sets and PCR conditions to amplify the ten epitopes are described as follows: (a) Epitopes 1 and 2. Primers: external sense (ES) CGA GTA GTG TTG GGT CGC GAA AG, external antisense (EA) AGG AAG ATA GAG AAA GAG CAA CCA, internal sense (IS) AGG CCT TGT GGT ACT GCC TGA, internal antisense (IA) AGG TTC CCT GTT GCA TAA TT. PCR conditions: 1 cycle $\left(95^{\circ} \mathrm{C}-5^{\prime}, 56^{\circ} \mathrm{C}-2^{\prime}, 72^{\circ} \mathrm{C}-1^{\prime}\right) ; 35 \mathrm{cy}-$ cles $\left(95^{\circ} \mathrm{C}-45^{\prime \prime}, 56^{\circ} \mathrm{C}-45^{\prime \prime}, 72^{\circ} \mathrm{C}-45^{\prime \prime}\right) ; 1$ cycle $\left(72^{\circ} \mathrm{C}-4^{\prime}\right)$. (b) Epitope 3 . Primers: (ES) TAA GGT CAT CGA TAC CCT, (EA) GAC CAG TTC ATC ATC ATA TC, (IS) GCG TCC GGG TTC TGG AAG AC, (IA) ATA GAT AGA GCA ATT GCA. PCR conditions: same as (a). (c) Epitope 4. Primers: (ES) ATC ACG GCG TAC GCC CAG CAG A, (EA) ATC GGC GTG CCT CGT GAC CA, (IS) AGC CTA ACT GGC CGG GAC AA, (IA) TCC GAG GAG CCG CAA GTG CA. PCR conditions: same as $(a)$. $(d)$ Epitope 5. Primers: (ES) AGC CTA ACT GGC CGG GAC AA, (EA) GAA CTT GCC GTA GGT GGA GT, (IS) TCA GAC CTT TAC TTG GTC AC, (IA) AGG GAC CTT GGT GCT TTT. PCR conditions: 1 cycle $\left(95^{\circ} \mathrm{C}-5^{\prime}, 54^{\circ} \mathrm{C}-1^{\prime}, 72^{\circ} \mathrm{C}-1^{\prime}\right) ; 35$ cycles $\left(95^{\circ} \mathrm{C}-45^{\prime \prime}, 54^{\circ} \mathrm{C}-45^{\prime \prime}, 72^{\circ} \mathrm{C}-\right.$ $\left.45^{\prime \prime}\right) ; 1$ cycle $\left(72^{\circ} \mathrm{C}-4^{\prime}\right)$. (e) Epitope 6. Primers (ES) ACG TAC TCC ACC TAC GGC AA, (EA) AAG GTA GGG TCA AGG CTG AA, (IS) CAT CCC AAC ATC GAG GAG GT, (IA) TTG CAG TCT ATC ACC GAG TC. PCR conditions: same as $(a)$. $(f)$ Epitopes 7, 8, and 9. Primers (ES) GAT GAG ATG GAA GAG TGC TC, (EA) CAG CGA GTG TGC ATG ATG CC, (IS) TGG GCG AAG CAT ATG TGG AA, (IA) ATG GCG GGC AGT AGA TTG AC. PCR conditions: 1 cycle $\left(95^{\circ} \mathrm{C}-5^{\prime}, 56^{\circ} \mathrm{C}-2^{\prime}, 72^{\circ} \mathrm{C}-1^{\prime}\right) ; 35$ cycles $\left(95^{\circ} \mathrm{C}-1^{\prime}\right.$, $\left.56^{\circ} \mathrm{C}-1^{\prime}, 72^{\circ} \mathrm{C}-1^{\prime}\right) ; 1$ cycle $\left(72^{\circ} \mathrm{C}-4^{\prime}\right)$. (g) Epitope 10 . Primers (ES) ACA GTC ACT GAG AGC GAC AT, (EA) CTG GTC ATA GCC TCC GTG AA, (IS) TCC CTC ACC GAG AGA CTT TA, (IA) same as EA. PCR conditions: 1 cycle $\left(95^{\circ} \mathrm{C}-5^{\prime}, 56^{\circ} \mathrm{C}-1^{\prime}, 72^{\circ} \mathrm{C}-1^{\prime}\right) ; 35$ cycles $\left(95^{\circ} \mathrm{C}-30^{\prime \prime}, 56^{\circ} \mathrm{C}-30^{\prime \prime}, 72^{\circ} \mathrm{C}-30^{\prime \prime}\right) ; 1$ cycle $\left(72^{\circ} \mathrm{C}-4^{\prime}\right)$.

PCR products containing the $\mathrm{HCV}$ fragment were sequenced with the corresponding internal HCV primers, Sequenase 2.0 (Amersham Corp., Arlington Heights, IL), ${ }^{35}$ S dATP (Amersham Corp.) using dideoxynucleotide chain-termination method according to the manufacturer's instructions, analyzed on a $6 \%$ denaturing acrylamide gel, and autoradiographed. Ambiguous or variant (i.e., non$\mathrm{HCV}-1$ ) sequences were confirmed by sequencing of both sense and antisense strands, and/or by sequencing of second independently amplified PCR product. In selected instances, sequence analysis of multiple PCR clones was performed using TA Cloning Kit (Invitrogen Corp., San Diego, CA) according to the manufacturer's instructions.

Statistical analysis. Fisher's exact test was used to assess the statistical significance of the association between prototype peptide-specific CTL response and variant viral peptide sequence. $P$ value $<0.05$ was considered to be significant. 


\section{Results}

Multispecificity and potential cross-reactivity of the $\mathrm{HCV}$ specific CTL response. To monitor the HCV-specific CTL response, PBMC from 13 chronic $\mathrm{HCV}$ patients and 15 uninfected blood donors were stimulated with a panel of 10 synthetic peptides corresponding to previously defined CTL epitopes derived from the prototype HCV-1 sequence (genotype 1a). Using experimental cutoffs derived from the uninfected controls as described in the Methods, a CTL response was observed in 68 of 130 possible assays (13 patients, 10 epitopes) (Fig. 1). Consistent with the previously described multispecificity of HCV-specific CTL response $(4,8,9)$, all of the infected patients responded to at least one of the peptides and the majority of the patients responded to four or more peptides. Interestingly, Patients 2, 7, and 13 responded to 7 of the 10 prototype peptides even though they were infected with genotype $2 \mathrm{~b}, 1 \mathrm{~b}$, and $3 \mathrm{a}$ viruses, respectively. Furthermore, peptide 4 (NS3 1073) and peptide 6 (NS3 1406) were recognized in the majority of patients despite relatively low amino acid sequence conservation ( 39 and $12 \%$, respectively). These results suggest either cross-reactivity of the CTL response between HCV subtypes or the existence of a CTL response to a homologous virus (through previous exposure or current infection by a minor species).

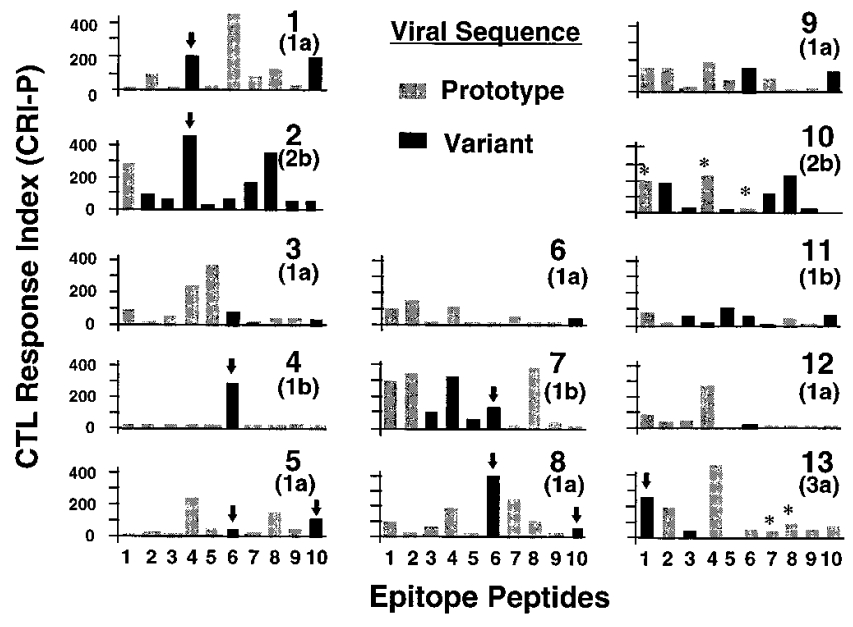

Figure 1. Prototype HCV-1 peptide-specific CTL response and viral peptide sequence analysis. Representative CTL responses to 10 prototype $\mathrm{HCV}-1$-derived peptides and the corresponding viral sequences are shown for 13 chronic HCV patients (1-13). The genotype of the infecting viruses are shown in parentheses below the patient identification number. CRI-P corresponds to the sum of cytotoxicity in eight replicate wells tested for each prototype peptide analyzed in a $4 \mathrm{~h}{ }^{51} \mathrm{Cr}$ release assay after $3 \mathrm{wk}$ of in vitro stimulation. CRI-P greater than the cutoff values provided in Methods (range 25.1-93.2) were considered positive. All responses shown reflect lysis of target cells pulsed with HCV-1 (genotype 1a)-derived peptides. Gray bars indicate that the peptide encoded by the infecting virus was identical to the HCV-1 prototype peptide used in the assay. Black bars indicate that a variant peptide was encoded by the infecting virus. Vertical arrows indicate the variant sequences selected for analysis of crossreactivity and immunogenicity (Figs. 2-4). The five loci where a change in viral peptide sequence (from prototype to variant) occurred at T2 are marked with an asterisk (*) (see Fig. 5 for analysis of cross-reactivity and immunogenicity).
Sequence heterogeneity of the viral epitopes. To correlate CTL responsiveness to each genotype 1a prototype peptide with the corresponding sequence encoded by the predominant viral species in individual patients, we determined the peptide sequences from serum-derived viral RNA by reverse transcription and direct PCR sequence analysis. As summarized in Fig. 2, a total of 122 sequences were determined at T1 (i.e., at the time of or before CTL analysis). For convenience, viral peptide sequences that differ from the prototype HCV-1 peptides are designated as variant, and those that are identical to the $\mathrm{HCV}-1$ peptide sequences are termed prototype. Variant viral sequences were present in 35/122 instances (29\%). Up to five amino acid residues differed from the prototype HCV-1 sequence in individual variant viral peptides. Substitutions at the predicted HLA-binding anchor residues (position 2 and $\mathrm{COOH}$ terminus) occurred in 11 peptide sequences although these substitutions were mostly conservative. The relative peptide sequence conservation in these patients tended to be higher than that expected based on the published full length sequences (shown at the bottom of Fig. 2 and also in Table II) presumably due to the high frequency of genotype 1a (7/13) in our viral isolates.

Coexistence of $\mathrm{HCV}$-1-specific CTL and variant viral peptide sequences. As suggested by the foregoing, CTL specific for the prototype peptides were often present in patients who were infected with viruses coding for variant peptide sequences at the corresponding epitope sites. For example, as shown in Figure 1, Patients 4 and 8 exhibited strong immunoreactivity against peptide 6 even though the corresponding epitope sequence in the infecting virus was different (indicated by the black bars) from the prototype peptide. Similarly, Patient 13 responded to peptide 1 (core 35) and Patient 2 to peptides 4 (NS3 1073), 7 (NS4B 1789), and 8 (NS4B 1807) despite the presence of variant viral sequences. Surprisingly, variant viral peptide sequences were detected more than three times more often when prototype-specific CTL were present (42\%) than when they were absent (13\%) (Table III). Conversely, prototype-specific CTL responses were detectable nearly twice as often in the presence of variant viral peptides $(80 \%)$ than the prototype viral peptides (44\%) (Table III). These differ-

Table II. HCV-1 (Genotype 1a) Derived Epitopes

\begin{tabular}{rlrlc}
\hline Epitope & Protein & $\begin{array}{c}\text { Amino acid } \\
\text { position }\end{array}$ & \multicolumn{1}{c}{ Sequence } & $\begin{array}{c}\text { Percentage } \\
\text { conservation* }\end{array}$ \\
\hline 1 & Core & 35 & YLLPRRGPRL & $76 \%$ \\
2 & Core & 131 & ADLMGYIPLV & $82 \%$ \\
3 & E1 & 257 & QLRRHIDLLV & $18 \%$ \\
4 & NS3 & 1073 & CINGVCWTV & $39 \%$ \\
5 & NS3 & 1169 & LLCPAGHAV & $12 \%$ \\
6 & NS3 & 1406 & KLVALGINAV & $12 \%$ \\
7 & NS4B & 1789 & SLMAFTAAV & $18 \%$ \\
8 & NS4B & 1807 & LLFNILGGWV & $76 \%$ \\
9 & NS4B & 1851 & ILAGYGAGV & $82 \%$ \\
10 & NS5B & 2727 & GLQDCTMLV & $18 \%$ \\
& & & & \\
\hline
\end{tabular}

* Amino acid sequence conservation derived from 17 full-length HCV sequences (Accession \#: P27958, P26664, D10749, Q00269, D11355, D13558, D10750, P26662, P26663, P29846, S18030, M96362, S62220, P26660, P26661, D17763, D28917). 


\begin{tabular}{|c|c|c|c|c|c|c|c|c|c|c|}
\hline \multirow{2}{*}{$\begin{array}{l}\text { Epitope No } \\
\text { (Location) } \\
\text { Sequence }\end{array}$} & 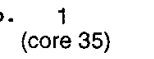 & $\stackrel{2}{2}$ (core 131) & $\begin{array}{c}3 \\
(E 1257)\end{array}$ & $\stackrel{4}{4}$ (NS3 1073) & $\begin{array}{c}5 \\
\text { (NS3 1169) }\end{array}$ & $\begin{array}{c}6 \\
\text { (NS3 1406) }\end{array}$ & $\begin{array}{c}7 \\
\text { (NS4B 1789) }\end{array}$ & $\begin{array}{c}8 \\
\text { (NS4B 1807) }\end{array}$ & $\stackrel{9}{9}$ (NS4B 1851) & $\begin{array}{c}10 \\
\text { (NS5B 2727) }\end{array}$ \\
\hline & YLIJPRRGPRL & ADLMGYIPLV & QLRRHIDLIV & CINGVCWTV & LLCPAGHAV & KLVALG INAV & SIMAFTAAV & LLFNILGGWV & ILAGYGAGV & GLQDCTMLV \\
\hline 1 (1a) & $\ldots-\ldots \ldots \ldots-\cdots$ & ---------- & $---\cdots-\cdots--$ & $-------A$ & $--\cdots-\cdots-\cdots$ & 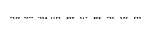 & $\ldots-\cdots \cdots$ & $\ldots$ & 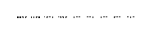 & $\mathrm{N} \cdots$ \\
\hline $2 \quad 2(2 b)$ & $\cdots \cdots-m-m-\cdots \cdots$ & $--V-$ & $\mathrm{N}-\cdots \mathrm{T}-\mathrm{V}-\mathrm{VI}-$ & $\mathrm{T}-\mathrm{S}--\mathrm{L}-\mathrm{Q}-$ & $\mathrm{V}--\mathrm{SR}----$ & $\mathrm{A}-\mathrm{RGM}-\mathrm{V}---$ & $-M---S--L$ & $\mathrm{I}-\mathrm{L}-\sim \mathrm{M}-\cdots \mathrm{L}$ & $V-\cdots-\cdots I$ & --IVEPI - - - \\
\hline \& 3 (1a) & $-----\ldots-\cdots$ & $m-m-m-m-m-n$ & $m-m-m-m-\cdots$ & $m-\cdots-\cdots \cdots$ & 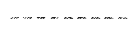 & 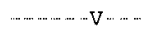 & 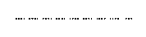 & $\ldots$ & 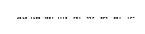 & $\cdots \cdots \cdot \mathbf{R} \cdots \cdots \cdots$ \\
\hline$\sum_{0}^{1} 4(1 b)$ & 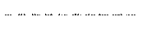 & -1 & 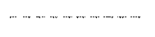 & 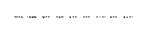 & 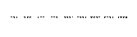 & $--\mathrm{S}--\mathrm{V} \cdots$ & $-\ldots-\ldots-\ldots$ & $\ldots \ldots \ldots \ldots$ & $---\cdots--$ & - \\
\hline 5 (1a) & 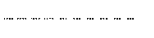 & 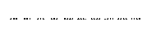 & . & 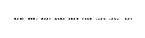 & 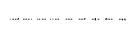 & $\ldots-\cdots--V-\cdots$ & $\ldots \ldots \ldots \ldots$ & $-m-m-m--$ & 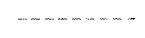 & $\cdots \mathrm{R} \cdots \cdots \cdots$ \\
\hline b $6(1 a)$ & 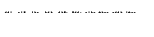 & (n) & . & 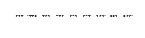 & - & 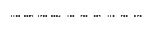 & - & $\ldots$ & 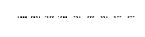 & $\cdots \mathrm{R} \cdots \cdots$ \\
\hline 7 (1b) & $m--m-m-m$ & 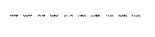 & TI $m \ldots-\cdots, \cdots \cdots$ & $\ldots--S I$ & $----\mathrm{S}-\cdots--$ & $\ldots \mathrm{SG}-\mathrm{L} \cdots$ & 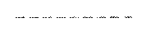 & $\cdots \cdots-\cdots--$ & $-\infty-\infty-\infty$ & (n) \\
\hline $\mathbf{Z} 8$ (1a) & $\ldots \ldots-\ldots-\cdots$ & - n-m-mom & $m-m-m-m-m$ & $-m-\cdots \cdots \cdots$ & $-n-\cdots-n-m-n$ & 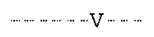 & 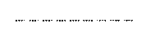 & 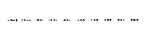 & ……… … & $\ldots, \mathrm{R} \cdots \cdots$ \\
\hline$\underset{+}{\boldsymbol{H}} 9(1 a)$ & $-\cdots--$ & $\cdots \cdots$ & $\cdots$ & - & - & $-\cdots---\mathrm{L}-\cdots$ & $\ldots \ldots$ & $\cdots$ & & $\cdots R$ \\
\hline $\begin{array}{lll} \pm & 10 & (2 b)\end{array}$ & 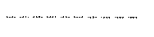 & $\cdots \cdots$ & $\star \star$ & 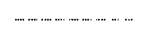 & $* *$ & 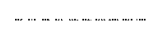 & $* *$ & * * & ** & nd \\
\hline 11 (1b) & $(-2)$ & $(-1-1-\cdots$ & $\mathrm{AI} \cdots \mathrm{V} \cdots$ & $-A-A$ & $-S-$ & $---\mathrm{SG}--\mathrm{L}---$ & $-\cdots--$ SI & $-\cdots$ & & $\mathrm{K} \cdots$ \\
\hline $12(1 a)$ & 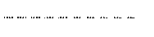 & $-\cdots+\cdots \cdots+\cdots, \cdots+\cdots$ & 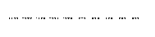 & 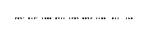 & nd & $\cdots-\cdots \cdots$ & $\ldots \ldots-\cdots$ & $-----\ldots \ldots-\cdots$ & $\cdots+\cdots$ & 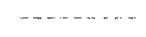 \\
\hline $13(3 a)$ & $-V-\cdots \cdots \cdots$ & $\ldots+\cdots$ & SI-S-V---- & $-\cdots \cdots$ & nd & $\cdots-\cdots-\cdots$ & - - - - - - & 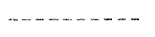 & $m-m-m$ & $\ldots$ \\
\hline $\begin{array}{l}\text { Number of } \\
\mathrm{HCV}-1 \text { Seq } \\
\text { at } \mathrm{T} 1(\%)\end{array}$ & $\begin{array}{l}12 / 13 \\
(92 \%)\end{array}$ & $\begin{array}{l}11 / 13 \\
(85 \%)\end{array}$ & $\begin{array}{c}8 / 12 \\
(67 \%)\end{array}$ & $\begin{array}{c}9 / 13 \\
(69 \%)\end{array}$ & $\begin{array}{c}7 / 10 \\
(70 \%)\end{array}$ & $\begin{array}{c}4 / 13 \\
(31 \%)\end{array}$ & $\begin{array}{l}10 / 12 \\
(83 \%)\end{array}$ & $\begin{array}{l}11 / 12 \\
(92 \%)\end{array}$ & $\begin{array}{l}11 / 12 \\
(92 \%)\end{array}$ & $\begin{array}{l}4 / 12 \\
(33 \%)\end{array}$ \\
\hline $\begin{array}{l}\% \text { Sequence } \\
\text { Conservation } \\
\text { in } 17 \text { full length } \\
\text { sequences } \\
\text { (from Table 2) }\end{array}$ & $76 \%$ & $82 \%$ & $18 \%$ & $39 \%$ & $12 \%$ & $12 \%$ & $18 \%$ & $76 \%$ & $82 \%$ & $18 \%$ \\
\hline
\end{tabular}

Figure 2. Viral peptide sequences at T1. The 122 viral peptide sequences that could be determined at T1 are shown. Dashes indicate identity with the prototype HCV-1 peptide sequence used in the initial screening CTL assays. Double asterisks (**) indicate sequences that could be amplified only at T2, all of which were variant. $n d$, Sequences that could not be amplified at T1 or T2. The relative conservation of each epitope sequence in the dominant virus populations in the 13 patients enrolled in this study, and in 17 full length HCV sequences included in GenBank database (also shown in Table II) are shown below each column.

ences were statistically significant $(P<0.0003)$, suggesting either CTL cross-reactivity or CTL selection of escape variants. These alternative hypotheses were tested in the next series of experiments.

CTL cross-reactivity and immunogenicity of variant $\mathrm{HCV}$ peptides. Viruses containing variant epitopes that are not recognized by prototype-specific CTL (i.e., not cross-reactive) and do not induce CTL themselves are potentially CTL escape variants. Among the $28 \mathrm{~T} 1$ variants associated with $\mathrm{HCV}-1$ prototype specific CTL (Table III), nine (marked with vertical arrows in Fig. 1) of the corresponding peptides were synthesized and tested for CTL cross-reactivity and immunogenicity in seven patients. Importantly, the variant peptides were neither cross-reactive nor immunogenic in four instances, compatible with CTL escape at these loci (Fig. 3). The amino acid substitutions in these variant peptides resulted in markedly reduced HLA-A2.1 binding affinity in three of the four instances, as shown in Table IV $A$. In contrast, the remaining five variant peptides were cross-reactive and four of them were

Table III. Viral Peptide Sequence at T1 and Prototype HCV-1 Peptide-Specific CTL Response

\begin{tabular}{|c|c|c|c|}
\hline \multirow[b]{2}{*}{ Viral peptide sequence } & \multicolumn{2}{|c|}{$\begin{array}{l}\text { CTL response to prototype } \\
\text { HCV-1 peptide }\end{array}$} & \multirow[b]{2}{*}{$\begin{array}{l}\text { Percentage with } \\
\text { CTL response }\end{array}$} \\
\hline & $\begin{array}{l}\text { Present } \\
(n=66)\end{array}$ & $\begin{array}{l}\text { Absent } \\
(n=56)\end{array}$ & \\
\hline Prototype $(n=87)$ & 38 & 49 & $44 \%$ \\
\hline Variant $(n=35)$ & 28 & 7 & $80 \%$ \\
\hline Percentage variant & $42 \%$ & $13 \%$ & $P<0.0003$ \\
\hline
\end{tabular}

also immunogenic, suggesting that the viruses did not escape the CTL response at these loci in these patients (Fig. 4). As expected, majority of these variant peptides could bind HLAA2.1 molecule with equal or greater efficiency than the corresponding prototype peptides, as shown in Table IV B. Overall, potential CTL escape variants were present in four out of seven patients $(57 \%)$ at $\mathrm{T} 1$.

Emergence of epitope variants over time. 74 viral peptides that were identical to the prototype $\mathrm{HCV}-1$ sequence at $\mathrm{T} 1$ were sequenced at a second time point (T2) in 12 patients after a mean period of 22 mo to determine if mutations might occur in the presence $(n=33)$ or absence $(n=41)$ of specific CTL pressure. Shift in viral peptide sequence from prototype to variant occurred in only five instances in two patients (asterisks in Fig. 1), three of which (3 out of 33, 9\%) were associated with CTL pressure, and two of which ( 2 out of $41,5 \%$ ) emerged without CTL pressure. In addition, sequence analysis of 22 of the 35 viral peptides that were already variant at $\mathrm{T} 1$ was also performed at T2. No further change in peptide sequence was observed at these loci.

As shown in Fig. 5, the five variant peptide sequences that emerged at T2 were tested for the ability to escape the CTL response. None of the three variants that emerged in the presence of prototype specific CTL was recognized by those CTL (Fig. 5, top), raising the possibility that these T2 variants may have escaped the CTL response to the wild-type peptide. However, two of these variant peptides, variant core 35 peptide in Patient 10 and variant NS4B 1807 peptide in Patient 13 were immunogenic themselves (Fig. 5, bottom), suggesting that the virus probably did not escape the CTL response at these loci. Indeed, for Patient 13, CTL specific for the variant NS4B 1807 peptide were present already at $\mathrm{T} 1$ and persisted for over $20 \mathrm{mo}$ after T2 (data not shown), suggesting the presence of a minor 


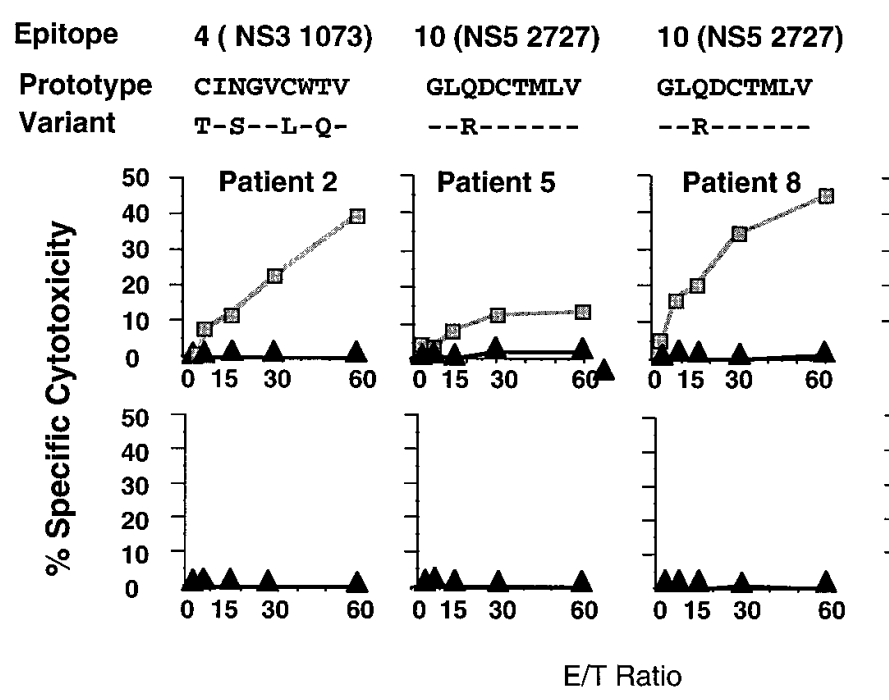

species coding for this immunogenic variant peptide at $\mathrm{T} 1$ even though no variant epitope sequences could be detected in 14 PCR clones we analyzed from this time point. The emergence of the viral species containing the variant NS4B 1807 sequence despite counterselective pressure at this site suggests that this CTL response is irrelevant and that the epitope variant may enjoy a survival advantage over the wild-type virus through undefined mechanisms. However, since this epitope is located in NS4B, the function of which is not yet determined, we cannot speculate about the impact that this particular sequence variation may have on virus life cycle. Interestingly, the HLA-binding affinity of the variant NS4B 1807 peptide in $\mathrm{Pa}-$ tient 13 was also 65-fold lower than the prototype, suggesting
Figure 3. Four noncross-reactive and nonimmunogenic variant peptides at T1. The prototype HCV-1 peptide sequences and corresponding variant viral peptide sequences of the infecting virus from the first sequence analysis (T1) are shown at the top of the figure. Dashes indicate identity with the prototype HCV-1 peptide. The top panel of graphs shows the cytolytic activity of CTL stimulated with the prototype peptide against targets pulsed with the same peptide (squares), and against targets pulsed with the corresponding variant peptide (triangles). The bottom panel of graphs show the immunogenicity of the variant peptide, using CTL stimulated with the variant peptide against targets pulsed with the same variant peptide (triangles).

Table IV. HLA-binding Affinity of Prototype and Variant Peptides

\begin{tabular}{|c|c|c|c|c|c|c|}
\hline \multirow[b]{2}{*}{ Patient } & \multirow[b]{2}{*}{ Epitope } & \multicolumn{2}{|c|}{ Peptide CTL activity } & \multicolumn{2}{|c|}{ HLA-A2.1 binding affinity $(\mathrm{nM})$} & \multirow{2}{*}{$\begin{array}{l}\text { Fold reduction in } \\
\text { HLA-A2.1 binding** }\end{array}$} \\
\hline & & Prototype & Variant* & Prototype & Variant & \\
\hline \multicolumn{7}{|c|}{$\mathrm{T} 1$ variants } \\
\hline A. 2 & NS3 1073 & + & - & 55 & 35 & 0.6 \\
\hline 5 & NS5 2727 & + & - & 18 & 421 & 23.4 \\
\hline 8 & NS5 2727 & + & - & 18 & 421 & 23.4 \\
\hline 13 & Core 35 & + & - & 189 & 3571 & 18.9 \\
\hline B. 1 & NS3 1073 & + & + & 55 & 2703 & 49.1 \\
\hline 4 & NS3 1406 & + & + & 449 & 344 & 0.8 \\
\hline 5 & NS3 1406 & + & + & 449 & 254 & 0.6 \\
\hline 7 & NS3 1406 & + & + & 449 & 292 & 0.7 \\
\hline 8 & NS3 1406 & + & + & 449 & 254 & 0.6 \\
\hline \multicolumn{7}{|c|}{$\mathrm{T} 2$ variants } \\
\hline C. 10 & Core 35 & + & + & 189 & 646 & 3.4 \\
\hline 10 & NS3 1073 & + & - & 55 & 36 & 0.7 \\
\hline 10 & NS3 1406 & - & - & 449 & 50000 & 111.4 \\
\hline 13 & NS4B 1789 & - & - & 26 & 42 & 1.6 \\
\hline 13 & NS4B 1807 & + & + & 192 & 12500 & 65.1 \\
\hline
\end{tabular}

*Cross-reactivity with the prototype peptide specific CTL and/or immunogenicity (as shown in Figs. 3-5). **Ratio between HLA-A2.1 binding affinities: variant peptide/prototype peptide. 


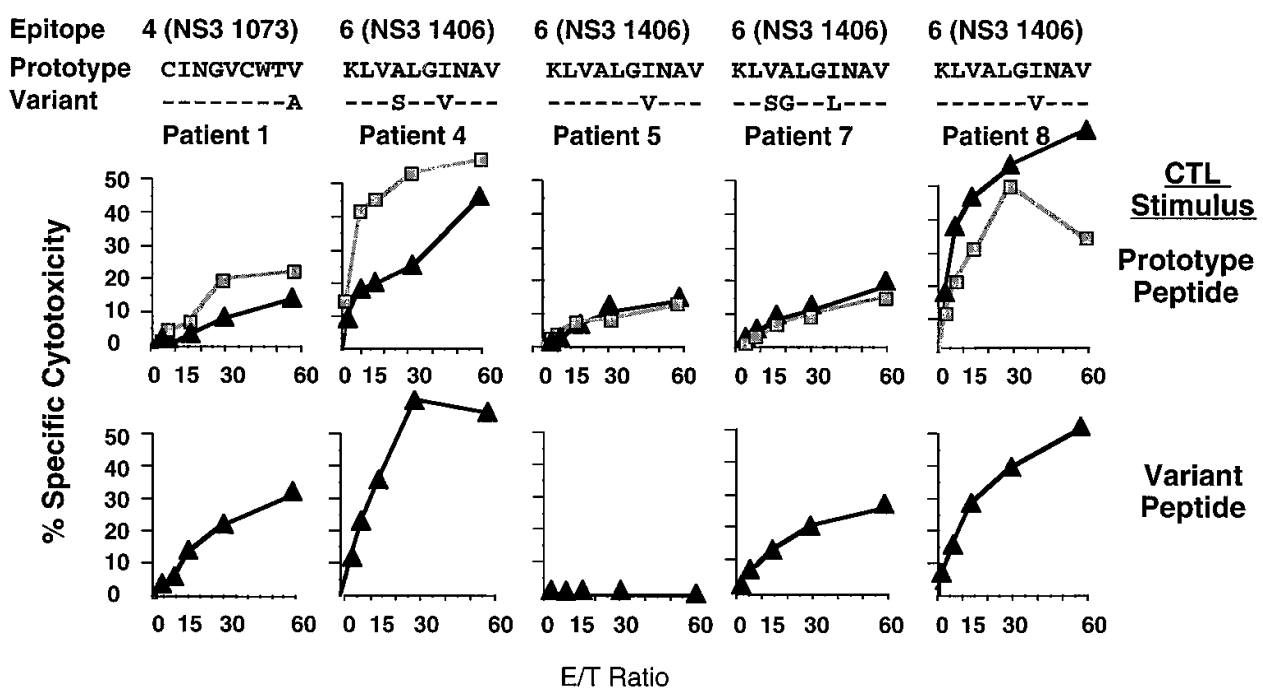

Figure 4. Five cross-reactive and immunogenic variant peptides at $\mathrm{T} 1$. The prototype $\mathrm{HCV}-1$ peptide sequences and corresponding variant viral peptide sequences of the infecting virus from the first sequence analysis (T1) are shown at the top of the figure. Dashes indicate identity with the prototype HCV-1 peptide. The top panel of graphs shows the cytolytic activity of CTL stimulated with the prototype peptide against targets pulsed with the same peptide (squares), and against targets pulsed with the corresponding variant peptide (triangles). The bottom panel of graphs show the immunogenicity of the variant peptide, using CTL stimulated with the variant peptide against targets pulsed with the same variant peptide (triangles). tested for its ability to antagonize CTL specific for wild-type (i.e., prototype HCV-1) peptide. As shown on Fig. 6, the cytolytic activity of wild-type peptide 4 (NS3 1073) was inhibited by the variant peptide, suggesting that the variant sequence not only escapes recognition by the prototype specific CTL, but it may also block CTL recognition of the wild-type virus at this locus in vivo. Consistent with its behavior as a T cell receptor antagonist, the variant NS3 1073 peptide was unimpaired in its HLA-binding affinity.

\section{Discussion}

It has been suggested that CTL selection of escape variants contributes to viral persistence during HIV, HTLV-1, and
HBV infection $(24,28-33)$. The role of CTL pressure and the selection of escape variants during chronic $\mathrm{HCV}$ infection is not well-defined, however, because a systematic analysis of CTL escape has not been done in such patients who regularly produce a multispecific CTL response to this virus $(3-5,8,9)$.

In this study, we tested the CTL escape hypothesis by examining the relationship between CTL pressure and viral peptide sequence at ten different potential epitope sites in 13 patients with chronic HCV infection. Our results can be summarized as follows: First, we observed a strong association between the presence of a prototype peptide specific CTL response and the existence of variant viral peptide sequences that suggested CTL selection. Second, in more than half of the patients who were infected by viruses encoding variant epitope

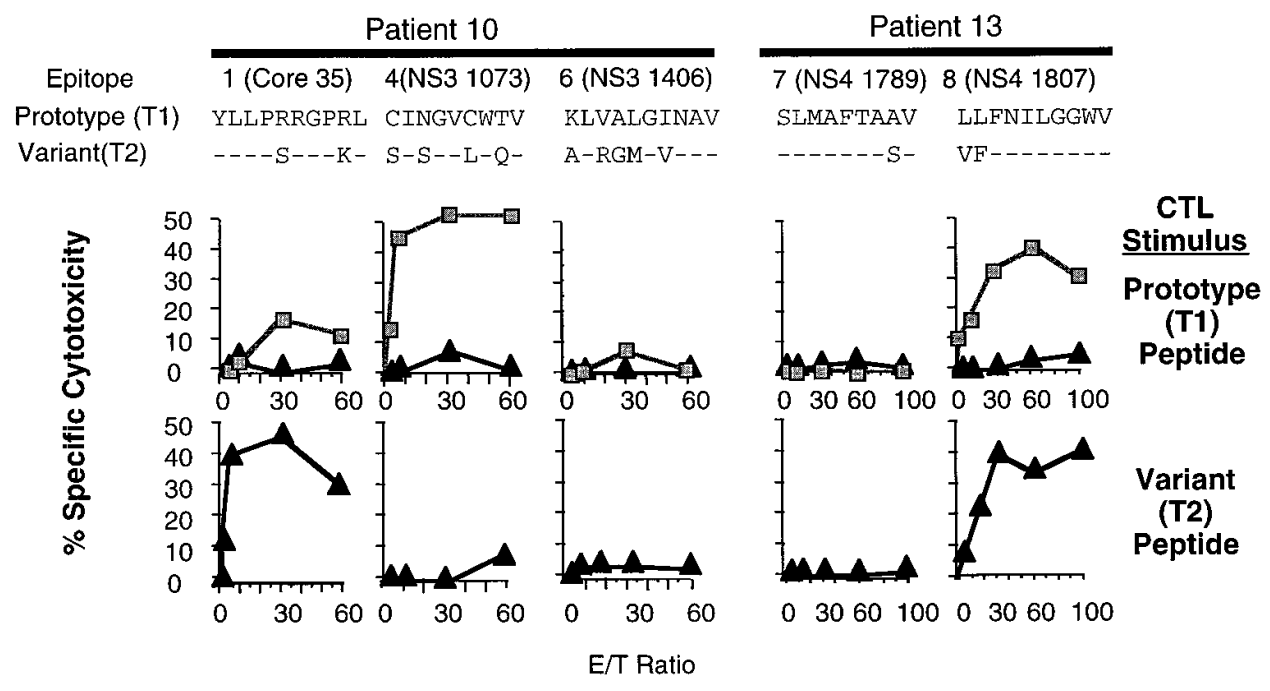

Figure 5. Five variant peptide sequences emerging at $\mathrm{T} 2$. The prototype (HCV-1) viral epitope sequences present at $\mathrm{T} 1$ and the variant viral epitope sequences that emerged at T2 in Patients 10 and 13 are shown at the top of the figure. The intervals between $\mathrm{T} 1$ and $\mathrm{T} 2$ in patients 10 and 13 were 10 and 45 mo, respectively. Dashes indicate identity with the prototype HCV-1 peptide sequence. The top panel of the graphs shows the cytolytic activity of CTL stimulated with the prototype peptide against targets pulsed with the same peptide (squares), and against targets pulsed with the variant peptide (triangles). The bottom panel of graphs shows the immunogenicity of the variant T2 peptide, using CTL stimulated with the variant peptide against targets pulsed with the same peptide (triangles). 


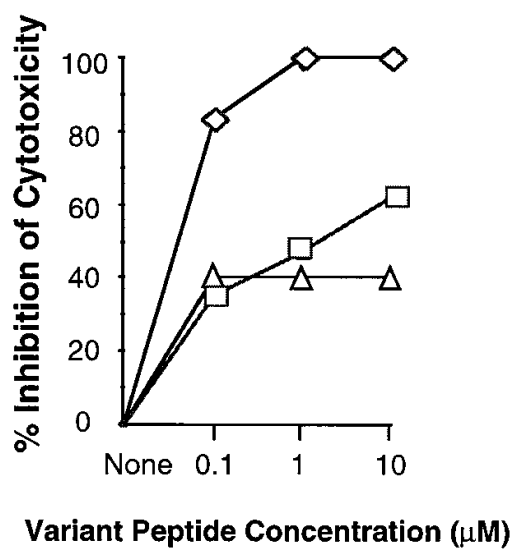

diamonds; $0.3 \mu \mathrm{M}$, squares; $1.0 \mu \mathrm{M}$, triangles) and then incubated with the variant peptide $(0.1,1,10 \mu \mathrm{M})$ for $1 \mathrm{~h}$ before performing a standard $4 \mathrm{~h}{ }^{51} \mathrm{Cr}$ release assay at an effector/target cell ratio of 60 . The percent specific cytotoxicity of NS3 1073 prototype peptide pulsed target cells in the absence of variant peptide was 60,37 , and $20 \%$ at $0.1,0.3$, and $1.0 \mu \mathrm{M}$ prototype peptide concentrations, respectively.

sequences, at least one of the variant peptides was not recognized by the existing CTL, suggesting that CTL selection may have already occurred at these loci before the time they entered our study. Third, in contrast to the foregoing, the emergence of a variant viral peptide sequence consistent with CTL escape was extremely rare during a follow-up interval of 10-46 mo, suggesting that CTL escape is not rapid in chronically infected patients and that it may actually occur as an early event in the infection when the CTL response is likely to be most vigorous.

These results are compatible with CTL selection of escape variants in chronic HCV infection. Indeed, when 122 individual prototype peptide-specific CTL responses are compared with the corresponding viral peptide sequences (Table III), the viral peptides encoded by the infecting viral species were much more frequently variant when prototype peptide specific CTL were detectable $(42 \%)$ than in the absence of CTL pressure $(13 \%)$. Likewise, most $(80 \%)$ of the variant viral peptides, but less than half $(44 \%)$ of the prototype viral peptides, were associated with prototype peptide specific CTL. Furthermore, in the absence of detectable CTL responses, the majority $(87 \%)$ of the corresponding viral peptide sequences were identical to the prototype peptides used for CTL analysis, consistent with absence of selection pressure at these loci in vivo.

Presumably, maintenance of a prototype peptide-specific CTL response in patients whose viruses encode a variant peptide reflects either cross-reactivity of the prototype and variant peptides, previous exposure to viral species encoding the prototype peptides (i.e., prior selection) or to concurrent exposure to a viral subpopulation encoding the prototype peptides not detectable by direct PCR sequencing (i.e., ongoing selection). CTL selection is especially likely if the variant peptides are not recognized by the coexisting prototype-specific CTL. In fact, we detected variant viral peptides that were neither cross-reactive with the prototype-specific CTL nor immunogenic themselves in four of the seven patients in whom variant viral peptide sequences coexisted with prototype-specific CTL (Fig. 3).
It is important to emphasize, however, that coexistence of a prototype-specific CTL response with a nonimmunogenic and noncross-reactive epitope variant does not prove CTL selection, per se. Unfortunately, in the absence of an efficient in vitro replication system or convenient animal model, the causal relationship between CTL and variant viral peptide sequence in HCV infection cannot be tested directly (34-36). Furthermore, our stimulation method does not allow us to distinguish between immunodominant versus subdominant epitopes nor could we study the CTL response and virus sequence from the onset of their infection. Nonetheless, the presence of variant viral peptides that are not recognized by CTL in several of our patients is consistent with the notion that CTL pressure on a mutable virus can result in the selection of escape variants, similar to other viral infections $(24,28-30,33,37,38)$.

In contrast to the relatively high frequency of CTL escape variants at $\mathrm{T} 1(57 \%)$, the emergence of CTL escape at $\mathrm{T} 2$ was relatively low $(8 \%)$. The most likely reason for this observation is that the CTL response at these loci was too weak to exert strong selection pressure and the follow-up period was probably much shorter than the duration of prior chronic infection in these patients. We are particularly attracted to the possibility that selection against viral species that expressed immunodominant epitopes may have already occurred at the time the patients first entered our study, and they were left with CTL responses to subdominant epitopes that may exert significantly less selection pressure, as has been suggested to occur in HIV infection $(31,39,40)$. This is compatible with our previous observation that the CTL response to $\mathrm{HCV}$ is not very vigorous during chronic infection (8). The fact that CTL escape during the first $16 \mathrm{wk}$ of infection preceded the onset of chronic HCV infection in an experimentally infected chimpanzee (22) is also consistent with the hypothesis that selection of escape variants may be a relatively early event in HCV infection.

The only evidence for CTL escape during our longitudinal analysis occurred within the NS3 1073 epitope. Interestingly, NS3 1073 is a particularly immunogenic epitope and CTL specific for this epitope have also been detected in the liver of a chronically infected patient using an antigen-nonspecific CTL stimulation strategy (3). Also, we have previously demonstrated sharp increases in NS3 1073-specific CTL precursor frequency that were accompanied by flares in serum ALT activity in two patients, suggesting that the CTL response to this epitope may be pathogenetically important (8). Moreover, as shown in Fig. 6, this variant was a CTL antagonist that could potentially abrogate recognition of both the wild-type and the variant virus in vivo, a more efficient mechanism for viral escape than passive nonrecognition $(19,28,29)$. The emergence of this CTL escape variant in Patient 10 was unaccompanied by any evidence of liver disease, fluctuations of ALT, or rise in viral load; however, this patient was also able to produce a CTL response to the variant core 35 epitope that emerged at T2 (Fig. 5), suggesting that immune adaptation to the changing virus may account for the clinical stability of this patient and the slowly progressive infection frequently observed in chronic $\mathrm{HCV}$ infection.

It is noteworthy that the loss of HLA-A2.1 binding affinity was generally in close agreement with the loss of CTL recognition of the variant viral peptides, as shown in Table IV. This is one obvious mechanism whereby mutations can lead to viral escape. Furthermore, the T2 variant of NS3 1073 peptide that 
emerged in Patient 10 could bind HLA A2.1 efficiently but it was not immunogenic itself, it was not recognized by prototype-specific CTL and it antagonized the ability of those CTL to recognize targets that express the prototype peptide. This provides another mechanism whereby virus sequence variations in natural infections could mediate viral evasion from the CTL response.

Despite the foregoing considerations, however, we are left with the challenge of explaining how $\mathrm{HCV}$ can escape from a multispecific CTL response. Simultaneous mutation at multiple CTL epitopes is extremely unlikely even in the highly mutable RNA viruses, and mutational loss of one or two of many epitopes may not significantly enhance viral survival (19). On the other hand, as suggested in HIV-1 infection (39), CTL escape could occur if an apparently multispecific response actually reflects the sequential induction of a series of narrowly focused CTL responses as a result of ongoing viral variation. In particular, viral escape from a dominant CTL response at the onset of infection could play a central role in viral persistence by enhancing viral survival when it is most susceptible to immune elimination (i.e., before the virus can spread to many cells or infect immune-privileged sites). In support of the foregoing considerations, Borrow et al. (31) recently demonstrated rapid selection of CTL escape variants in an HIV-infected patient by an immunodominant HLA-B44-restricted CTL response to the viral envelope glycoprotein at the early phase of infection, and a coincident rise in CTL responsiveness to other viral proteins. Similarly, Goulder et al. (40) also reported selection of mutations affecting an immunodominant HLA-A2.1 restricted HIV-1 gag epitope early in the infection associated with diversion of CTL responsiveness to a polymerase epitope and the disappearance of gag-specific CTL, suggesting that patterns of immunodominance may be influenced by epitope mutations.

In conclusion, we suggest that early escape from immunodominant CTL responses may be an important determinant of $\mathrm{HCV}$ persistence. A comprehensive, longitudinal analysis of the kinetics, vigor, and breadth of $\mathrm{T}$ cell response relative to the viral load and sequence variation soon after the onset of $\mathrm{HCV}$ infection must now be performed to better define the role of CTL escape in the early phase of this disease.

\section{Acknowledgments}

We would like to thank Dr. James Koziol (Division of Biomathematics, The Scripps Research Institute, La Jolla, CA) for statistical analysis; Dr. Andrew Conrad (National Genetics Institute, Los Angeles, CA) for HCV genotyping; Dr. Robert Kokka (Chiron Corporation, Emeryville, CA) for HCV bDNA assays; Linda Wilkes, Julie Hansen, Kay Waite, Sue Dastrup, Priscilla Crisler for assistance in patient recruitment; Colleen Cunningham for drawing the blood and coordinating patient visits; Kendis Cox and Tony Mondala for help with processing blood samples; Ms. Patty Fowler and Josan Chung for many invaluable technical suggestions and helpful discussions; and Ms. Jennifer Newmann and Ms. Pat Puccini for expert assistance in manuscript preparation. We are also indebted to Dr. John Holland, Dr. Esteban Domingo, Dr. Jesse Summers, Dr. Yukihiro Shimizu, Dr. Kazuhiro Kakimi, and Dr. Veronique Juillard for helpful discussions.

This study was supported by grants AI20001 and MO1 RR00833 from the National Institutes of Health, the Sam and Rose Stein Endowment fund, and a grant from Cytel Corporation. K.M. Chang was supported by NIH training grant 2T32DKO7202 through the Univer- sity of California, San Diego, the American Liver Foundation Amgen Postdoctoral Supplementary Research Fellowship Award, and the Amgen/AASLD/ALF Research Development Award. B. Rehermann was supported by grants Re 1017/1-1 and Re1017/2-1 from the Deutsche Forschungsgemeinschaft, Bonn, Germany. This is manuscript number 10876-MEM from The Scripps Research Institute.

\section{References}

1. Koziel, M.J., D. Dudley, J.T. Wong, J. Dienstag, M. Houghton, R. Ralston, and B.D. Walker. 1992. Intrahepatic cytotoxic T lymphocyte specific for hepatitis C virus in persons with chronic hepatitis. J. Immunol. 149:3339-3344.

2. Koziel, M.J., D. Dudley, N. Afdhal, Q.-L. Choo, M. Houghton, R. Ralston, and B.D. Walker. 1993.. Hepatitis C virus (HCV)-specific cytoxic T lymphocytes recognize epitopes in the core and envelope proteins of HCV.J. Virol. 67:7522-7532.

3. Koziel, M.J., D. Dudley, N. Afdhal, A. Grakoui, C.M. Rice, Q.-L. Choo, M. Houghton, and B.D. Walker. 1995. HLA class I-restricted cytotoxic T lymphocytes specific for hepatitis $\mathrm{C}$ virus. Identification of multiple epitopes and characterization of patterns of cytokine release. J. Clin. Invest. 96:2311-2321.

4. Cerny, A., J.G. McHutchison, C. Pasquinelli, M.E. Brown, M.A. Brothers, B. Grabscheid, P. Fowler, M. Houghton, and F.V. Chisari. 1995. Cytotoxic T lymphocyte response to hepatitis $\mathrm{C}$ virus-derived peptides containing the HLA A2.1 binding motif. J. Clin. Invest. 95:521-530.

5. Battegay, M., J. Fikes, A.M. Di Bisceglie, P.A. Wentworth, A. Sette, E. Celis, W.-M. Ching, A. Grakoui, C.M. Rice, K. Kurokohchi, et al. 1995. Patients with chronic hepatitis $\mathrm{C}$ have circulating cytotoxic $\mathrm{T}$ cells which recognize hepatitis $\mathrm{C}$ virus-encoded peptides binding to HLA-A2.1 molecules. J. Virol. 69: 2462-2470.

6. Houghton, M., A. Weiner, J. Han, G. Kuo, and Q.-L. Choo. 1991. Molecular biology of the hepatitis $\mathrm{C}$ viruses: implications for diagnosis, development and control of viral disease. Hepatology. 14:381-388.

7. Alter, M.J., H.S. Margolis, K. Krawczynski, F.N. Judson, A. Mares, W.J. Alexander, P.Y. Hu, J.K. Miller, M.A. Gerber, R.E. Sampliner, E.L. Meeks, M.J. Beach, and Non-B Hepatitis Study Team The Sentinel Counties Chronic Non-A. 1992. The natural history of community-acquired hepatitis $\mathrm{C}$ in the United States. N. Engl. J. Med. 327:1899-1905.

8. Rehermann, B., K.-M. Chang, J.G. McHutchison, R. Kokka, M. Houghton, and F.V. Chisari. 1996. Quantitative analysis of the peripheral blood cytotoxic $\mathrm{T}$ lymphocyte response in patients with chronic hepatitis $\mathrm{C}$ virus infection. J. Clin. Invest. 98:1432-1440.

9. Rehermann, B., K.-M. Chang, J.G. McHutchison, R. Kokka, M. Houghton, C.M. Rice, and F.V. Chisari. 1996. Differential cytotoxic T-lymphocyte responsiveness to the hepatitis B and C viruses in chronically infected patients. $J$. Virol. 70:7092-7102.

10. Botarelli, P., M.R. Brunetto, M.A. Minutello, P. Calvo, D. Unutmaz, A.J. Weiner, Q.-L. Choo, J.R. Shuster, G. Kuo, F. Bonino, M. Houghton, and S. Abrignani. 1993. T-lymphocyte response to hepatitis $\mathrm{C}$ virus in different clinical courses of infection. Gastroenterology. 104:580-587.

11. Hoffmann, R.M., H.M. Diepolder, R. Zachoval, F.-M. Zweibel, M.-C. Jung, S. Scholz, H. Nitschko, G. Riethmuller, and G.R. Pape. 1995. Mapping of immunodominant CD4+ T lymphocyte epitopes of hepatitis $\mathrm{C}$ virus and their relevance during the course of chronic infection. Hepatology. 21:632-638.

12. Diepolder, H.M., R. Zachoval, R.M. Hoffmann, E.A. Wierenga, T. Santantonio, M.-C. Jung, D. Eichenlaub, and G.R. Pape. 1995. Possible mechanism involving T-lymphocyte response to non-structural protein 3 in viral clearance in acute hepatitis C virus infection. Lancet (N. Am Ed.). 346:1006-1007.

13. Ferrari, C., A. Valli, L. Galati, A. Penna, P. Scaccaglia, T. Guiberti, C. Schianchi, G. Missale, M.G. Marin, and F. Fiaccadori. 1994. T-cell response to structural and nonstructural hepatitis $\mathrm{C}$ virus antigens in persistent and self-limited hepatitis C virus infections. Hepatology. 19:286-295.

14. Hiroishi, K., H. Kita, M. Kojima, H. Okamoto, T. Moriyama, T. Kaneko, T. Ishikawa, S. Ohnishi, T. Aikawa, N. Tanaka, Y. Yazaki, K. Mitamura, and M. Imawari. 1997. Cytotoxic T lymphocyte response and viral load in hepatitis C virus infection. Hepatology. 25:705-712.

15. Martell, M., J.I. Esteban, J. Quer, J. Genesca, A. Weiner, R. Esteban, J. Guardia, and J. Gomez. 1992. Hepatitis C virus (HCV) circulates as a population of different but closely related genomes: quasispecies nature of $\mathrm{HCV}$ genome distribution. J. Virol. 66:3225-3229.

16. Martell, M., J.I. Esteban, J. Quer, V. Vargas, R. Esteban, J. Guardia, and J. Gomez. 1994. Dynamic behavior of hepatitis C virus quasispecies in patients undergoing orthotopic liver transplantation. J. Virol. 68:3425-3436.

17. Steinhauer, D.A., and J.J. Holland. 1987. Rapid evolution of RNA viruses. Annu. Rev. Microbiol. 41:409-433.

18. Domingo, E., C. Escarmis, N. Sevilla, N. Moya, S.F. Elena, J. Quer, I.S. Novella, and J.J. Holland. 1996. Basic concepts in RNA virus evolution. FASEB J. 10:859-864.

19. Franco, A., C. Ferrari, A. Sette, and F.V. Chisari. 1995. Viral mutations, $\mathrm{T}$ cell receptor antagonism and escape from the immune response. In Current Opinion in Immunology. A. Sher and R. Ahmed, editors. Current Biology Ltd. 
London. 524-531.

20. Alter, H.J. 1995. To C or not to C: these are the questions. Blood. 85 : 1681-1695.

21. Chang, K.M., B. Rehermann, and F.V. Chisari. 1997. Immunopathology of hepatitis C. In Springer Seminars in Immunopathology. V. Agnello, editor. Springer-Verlag, Geneva. 19:57-68.

22. Weiner, A., A.L. Erickson, J. Kansopon, K. Crawford, E. Muchmore, A.L. Hughes, M. Houghton, and C.M. Walker. 1995. Persistent hepatitis C virus infection in a chimpanzee is associated with emergence of a cytotoxic T lymphocyte escape variant. Proc. Natl. Acad. Sci. USA. 92:2755-2759.

23. Koup, R.A. 1994. Virus escape from CTL recognition. J. Exp. Med. 180: $779-782$

24. Bertoletti, A., A. Sette, F.V. Chisari, A. Penna, M. Levrero, M. DeCarli, F. Fiaccadori, and C. Ferrari. 1994. Natural variants of cytotoxic epitopes are T cell receptor antagonists for antiviral cytotoxic T cells. Nature (Lond.). 369: 407-410.

25. Sette, A., J. Sidney, M.-F. del Guercio, S. Southwood, J. Ruppert, C. Dahlberg, H.M. Grey, and R.T. Kubo. 1994. Peptide binding to the most frequent HLA-A class I alleles measured by quantitative molecular binding assays. Mol. Immunol. 31:813-822.

26. Chomczynski, P., and N. Sacchi. 1987. Single-step method of RNA isolation by acid guanidinium thiocyanate-phenol-chloroform extraction. Anal. Biochem. 162:156-159.

27. Kwok, S., and R. Higuchi. 1989. Avoiding false positives with PCR. Nature (Lond.). 339:237-238.

28. Klenerman, P., S. Rowland-Jones, S. McAdams, J. Edwards, S. Daenke, D. Lalloo, B. Koppe, W. Rosenberg, D. Boyd, A. Edwards, et al. 1994. Cytotoxic T-cell activity antagonized by naturally occurring HIV-1 Gag variants. Nature (Lond.). 369:403-407.

29. McMichael, A.J., and R. E. Phillips. 1997. Escape of human immunodeficiency virus from immune control. Annu. Rev. Immunol. 15:271-276.

30. Niewiesk, S., S. Daenke, C.E. Parker, G. Taylor, J. Weber, S. Nightingale, and C.R. Bangham. 1995. Naturally occurring variants of human T-cell leukemia virus type I Tax protein impair its recognition by cytotoxic $\mathrm{T}$ lymphocytes and the transactivation function of Tax. J. Virol. 69:2649-2653.

31. Borrow, P., H. Lewicki, X. Wei, M.S. Horwitz, N. Peffer, H. Meyers, J.A. Nelson, J.E. Gairin, B.H. Hahn, M.B.A. Oldstone, and G.M. Shaw. 1997. Antiviral pressure exerted by HIV-1-specific cytotoxic T lymphocytes (CTLs) during primary infection demonstrated by rapid selection of CTL escape virus. Nat. Med. 3:205-211.

32. Goulder, P.J.R., R.E. Phillips, R.A. Colbert, S. McAdam, G. Ogg, M.A Nowak, P. Giangrande, G. Luzzi, B. Morgan, A. Edwards, A.J. McMichael, and S. Rowland-Jones. 1997. Late escape from an immunodominant cytotoxic T-lymphocyte response associated with progression to AIDS. Nat. Med. 3:212-217.

33. Bertoletti, A., A. Costanzo, F.V. Chisari, M. Levrero, M. Artini, A. Sette, A. Penna, T. Giuberti, F. Fiaccadori, and C. Ferrari. 1994. Cytotoxic T lymphocyte response to a wild type hepatitis B virus epitope in patients chronically infected by variant viruses carrying substitutions within the epitope. $J$. Exp. Med. 180:933-943.

34. Shimizu, Y.K., A. Iwamoto, M. Hijikata, R.H. Purcell, and H. Yoshikura. 1992. Evidence for in vitro replication of hepatitis C virus genome in a human T cell line. Proc. Natl. Acad. Sci. USA. 89:5477-5481.

35. Cristiano, K., A.M. Di Bisceglie, J.H. Hoofnagle, and S.M. Feinstone. 1991. Hepatitis C viral RNA in serum of patients with chronic non-A, non-B hepatitis: detection by the polymerase chain reaction using multiple primer sets. Hepatology. 14:51-55.

36. Pasquinelli, C., J.M. Shoenberger, J.-S. Chung, K.-M. Chang, M. Selby, K. Berger, R. Lesniewski, M. Houghton, and F.V. Chisari. 1997. Hepatitis C virus core and E2 protein expression in transgenic mice. Hepatology. 25:719-727.

37. Aebischer, T., D. Moskophidis, U.H. Rohrer, R.M. Zinkernagel, and H. Hengartner. 1991. In vitro selection of lymphocytic choriomeningitis virus escape mutants by cytotoxic T lymphocytes. Proc. Natl. Acad. Sci. USA. 88: 11047-11051.

38. Pircher, H., D. Moskophidis, U. Rohrer, K. Burki, H. Hengartner, and R.M. Zinkernagel. 1990. Viral escape by selection of cytotoxic T-cell-resistant virus variants in vivo. Nature (Lond.). 346:629-633.

39. Nowak, M.A., R.M. May, R.E. Phillips, S. Rowland-Jones, D.G. Lalloo, S. McAdams, P. Klenerman, B. Koppe, K. Sigmund, and C.R.M. Bangham. 1995. Antigenic oscillations and shifting immunodominance in HIV-1 infections. Nature (Lond.). 375:606-611.

40. Goulder, P.J.R., A.K. Sewell, D.G. Lalloo, D.A. Price, J.A. Whelan, J. Evans, G.P. Taylor, G. Luzzi, P. Giangrande, R.E. Phillips, and A.J. McMichael. 1997. Patterns of immunodominance in HIV-1-specific cytotoxic T lymphocyte responses in two human histocompatibility leukocyte antigens (HLA)-identical siblings with HLA-A*0201 are influenced by epitope mutation. J. Exp. Med. 185:1423-1433. 